\title{
The Relationship among Nonword Repetition, Age, Vocabulary and Articulation Ability
}

\author{
Somi Jung, , Seunghee $\mathrm{Ha}^{\mathrm{b}}$ \\ ${ }^{a}$ Graduate Program in Speech Language Pathology, Hallym University, Chuncheon, Korea \\ ${ }^{b}$ Division of Speech Pathology and Audiology, Audiology and Speech Pathology Research Institute, Hallym University, Chuncheon, Korea
}

\author{
Correspondence: Seunghee $\mathrm{Ha}, \mathrm{PhD}$ \\ Division of Speech Pathology and Audiology, \\ Audiology and Speech Pathology Research \\ Institute, Hallym University, 1 Hallimdaehak-gil, \\ Chuncheon 24252, Korea \\ Tel: $+82-33-248-2215$ \\ Fax: +82-33-256-3420 \\ E-mail: shha@hallym.ac.kr
}

Received: January 5, 2017

Revised: February 19, 2017

Accepted: February 28, 2017

We want to thank Dr. Min Jung Kim for her suggestions on the scoring systems of word test and nonword repetition test and her comments on drafts of this manuscript.

\begin{abstract}
Objectives: This study aims to investigate developmental patterns of nonword repetition scores in 3- to 5-year-old typically developing children and examine whether and to what extent nonword repetition scores are related to age, vocabulary and articulatory skills. Methods: A total of 141 children (3-year age group, 37; 4-year age group, 52; 5-year age group, 52) participated in this study. Nonword repetition, articulation, and receptive and expressive vocabulary tests were administrated. Nonword repetition scores, word length and phoneme scores of the word test from Children Articulation and Phonology Profile, percentage of consonants correct from the Assessment of Phonology and Articulation for Children, and raw scores from Receptive \& Expressive Vocabulary Test (REVT) were obtained. Results: Five-year-old children showed significantly higher nonword repetition scores than 3- and 4-year-old children. No significant difference existed between 3- and 4-year-old children. The results showed that nonword repetition scores were positively related to word length and phoneme scores of the word test and the raw scores of REVT. The regression analysis showed that word length scores and raw scores of the receptive vocabulary test significantly predict nonword repetition scores. Conclusion: This study suggests that nonword repetition performance reflect articulation skills and receptive vocabulary. The results support the clinical usefulness of nonword repetition task for screening children who may be at risk for speech and language disorders.
\end{abstract}

Keywords: Nonword repetition, Age, Vocabulary, Articulatory ability 비단어(nonword)를 정확하게 따라말하기 위해서는 제시된 소리 의 음향학적 신호를 적절하게 지각하고, 지각된 음향신호를 음운 적으로 표상하고 기억해야 한다. 그리고 머릿속에 있는 음운표상 을 적절한 조음움직임으로 계획하고, 근육움직임을 실행해야 말 산출이 가능해진다. 즉, 비단어를 따라말하기 위해서는 말소리 지 각 및 인지, 청각정보처리, 음운기억, 말 운동 프로그래밍 및 산출과 같은 일련의 과정이 필요하다. 학령전기 아동의 비단어 따라말하기 과제의 수행력은 일반적으로 3 세에 가장 크게 발달하며 연령이 높 아지면서 이후에도 점차적으로 향상되는 모습을 보인다(Gathercole \& Baddeley, 1989; Hwang \& Ha, 2010; Roy \& Chiat, 2004). 서 로 상호보완적인 관계에 있는 일련의 말 처리 및 산출 능력이 적절 하게 발달하지 않거나 문제를 보인다면 비단어를 따라말하는 것에 어려움을 보이게 된다(Archibald \& Joanisse, 2009).
비단어 따라말하기 과제는 음운기억 및 어휘발달과 밀접한 관련 이 있다. 익숙지 않은 비단어를 보유하고 즉각적으로 따라말하기 위해서는 음운기억이 필수적이다. 음운기억은 작업기억의 하위 체 계인 음운루프와 관련이 깊다. Baddeley (1986)의 작업기억 모델에 따르면 음운루프는 음운저장소와 조음메커니즘으로 구성되어 있 는데, 음운저장소에서는 청각적으로 제시된 음운정보를 1.5-2초 동안 보관하고 있고, 조음메커니즘에서는 소리를 내지 않고 되뇌는 과정을 통해 저장시간을 증가시킨다고 한다. 즉, 음운기억을 위해서 는 음운정보를 효율적으로 저장하고 이를 지속적으로 보유하는 능력이 필요하다. 청각적으로 제시된 음운정보를 짧은 시간 안에 음운표상으로 만들기 위해서는 음운정보를 음운저장소에 보관하 는 과정과 이를 유지하기 위한 리허설 과정이 지속적으로 반복되어 야 한다. 음운기억은 언어발달 초기에 형성되어 점진적으로 발달하 
며 아동의 어휘와 읽기발달에 중요한 영향을 준다. 아동은 단어의 음운정보를 머릿속에서 적절하게 유지하고 음운, 의미 및 어휘표상 으로 저장하는 과정을 통해 어휘 습득을 이룬다. 새로운 단어를 학 습하는데 주된 역할을 하는 것이 음운기억이다(Baddeley, Gathercole, \& Papagno, 1998). 음운기억이 어휘발달에 영향을 주고, 어휘 습득을 예측할 수 있다는 연구 결과에 따라 국내외에서는 학령전 기 아동을 대상으로 비단어 따라말하기를 통해 음운기억을 살펴 보는 연구가 활발하게 이루어지고 있다(Archibald \& Joanisse, 2009; Gathercole, 2006; Lee \& Sim, 2003). 비단어 따라말하기는 시각적 단서와 의미적 정보가 제시되지 않고 산출을 위해서 의미 및 어휘 표상이 필요하지 않기 때문에 음운기억을 비교적 빠르고 정확하게 측정할 수 있는 과제이다(Gathercole \& Baddeley, 1989).

비단어 따라말하기 과제는 음운기억 및 어휘발달뿐만 아니라 말 처리 및 산출 능력과도 밀접한 관련이 있다. 말 처리 모델에서는 비 단어를 따라말하는 동안 거치는 말 산출 과정을 입력, 표상, 산출의 세 단계로 구분하여 설명한다. 그 중 어휘저장소에 위치한 음운표 상은 장기기억 속에 저장되어 다른 단어와 해당 단어를 변별하는 말소리 정보를 의미한다(Stackhouse \& Wells, 1997). Shriberg 등 (2009)은 일반아동과 조음장애아동을 대상으로 비단어 따라말하 기 수행력을 살펴보았다. 이 연구에서는 말 처리 과정을 보기 위하 여 말 산출 계획과 운동 프로그래밍, 청지각적 부호화, 기억용량의 3 가지 영역으로 나누어 살펴보았다. 조음장애아동들은 모든 영역 에서 낮은 수행력을 나타냄으로써 일반아동과 비교하여 말 산출계 획과 운동 프로그래밍, 청지각적 부호화, 기억용량 등의 어려움으 로 인하여 비단어 따라말하기 수행에서 저조한 수행력을 보인다고 하였다. 조음장애아동이 단순히 말 산출 영역뿐만 아니라 음운표 상과 관련한 영역에서도 문제를 보여 말소리 상의 오류를 보임을 제 안하고 있다. 또한 Sutherland와 Gillon (2005) 연구도 비단어 따라 말하기 과제를 통해 음운정보의 보유 및 저장, 음운표상의 형성 및 인출 과정을 살펴볼 수 있음을 바탕으로 조음음운장애와 음운표 상과의 관련성을 설명하였고, 음운표상이 적절하게 이루어지지 않 을 경우 조음음운장애가 될 수 있음을 보여주었다. 비단어 따라말 하기는 의미 있는 단어를 따라말하는 과제와 비교해서 단어의 친 숙도와 어휘 지식 및 문화적 배경 등의 영향을 받지 않는다. 따라서 비단어 따라말하기는 언어적 요소 중 음운적인 요소에 집중하면 서 음운 처리 과정뿐만 아니라 말 운동 측면도 살펴볼 수 있다. 비단 어 따라말하기를 수행하기 위해서는 조음 운동의 협응이 적절하게 이루어져야 하며, 그 수행력은 비단어 과제의 조음복잡성과 개인 의 조음 운동 능력에 따라 다르게 나타난다(Sasisekaran, Smith, Sadagopan, \& Weber-Fox, 2010; Walsh, Smith, \& Weber-Fox, 2006).
요컨대 비단어 따라말하기 과제를 통해 음운기억을 포함하여 청 각정보재인, 음운표상, 말 운동 프로그래밍, 말소리 산출 능력 등을 살펴볼 수 있다. 따라서 다수의 선행연구가 말.언어발달상의 문제 를 보이는 아동을 짧은 시간 동안 빠르게 선별해내기 위한 임상적 지표로 비단어 따라말하기 과제가 유용하게 쓰일 수 있음을 제안 하고 있다(Chiat \& Roy, 2007; Lee \& Sim, 2003; Lee, 2010; Shriberg et al., 2009; Stark \& Blackwell, 1997). 또한 영어권을 비롯해서 다양 한 언어권 연구에서 단순언어장애아동들이 비단어 따라말하기 과 제에서 일관되게 낮은 수행력을 보인다는 연구 결과들이 발표되고 있다(Bortolini et al., 2006; Dispaldro, Leonard, \& Deevy, 2013; Sahlen, Reuterskiod-Wagner, Nettelbladt, \& Radeborg, 1999; Stokes, Wong, Fletcher, \& Leonard, 2006).

최근 국내연구에서도 일반아동, 말 늦은 아동, 언어장애, 조음장 애아동들을 대상으로 비단어 따라말하기와 관련된 연구가 활발하 게 진행되고 있다. 먼저 일반아동을 대상으로 진행된 국내연구를 살펴보면, 일반아동의 비단어 따라말하기를 살펴본 Hwang과 $\mathrm{Ha}$ (2010)는 수도권·춘천지역 2-5세 아동 80명을 대상으로 2-3세 아동 의 숙달연령에 해당하는 자음으로 구성된 1-4음절 비단어를 통해 연령집단과 음절길이에 따른 수행력을 살펴보았다. 그 결과, 비단어 따라말하기는 2-3세에서 가장 크게 발달하였으며, 연령이 증가함 에 따라 전반적인 비단어 따라말하기 수행력이 높아지고, 음절길이 에 대한 수행력도 향상됨을 보여주었다. Hwang (2015)은 경기·충 청지역 5-9세 아동 152 명을 대상으로 발달적으로 늦게 발달하는 초 성 / ㅅ/, / ㅆ/, /리를 제외한 자음으로 구성된 2-5음절 비단어를 통 해 따라말하기를 살펴본 결과, 비단어의 길이가 짧고 아동의 연령 이 높아질수록 비단어 따라말하기 수행력이 향상되었다. 또한, 종 성을 포함해 조음복잡성이 높은 비단어 과제가 자음-모음 $(\mathrm{CV})$ 음 절구조로만 구성된 비단어보다 따라말하는 것이 유의미하게 어려 운 것으로 나타났다. 비단어의 길이 효과는 연령이 낮을수록 더 크 게 나타났다. 말 늦은 아동의 비단어 따라말하기를 살펴본 $\mathrm{Oh}$ 와 Yim (2013)은 2-3세의 일반아동과 말 늦은 아동, 총 40 명을 대상으 로 비단어 따라말하기 수행력 및 여러 변인들 간의 관계를 살펴보 았다. 그 결과, 비단어 따라말하기 수행에서 두 집단 모두 음절의 길 이가 길수록 낮은 수행력을 보였다. 이는 2-3세의 말 늦은 아동과 정상아동이 아직 충분히 발달되지 않은 음운기억, 청각처리와 같 은 능력으로 인해 비단어 따라말하기의 저조한 수행을 보였다고 설 명하였다. 또한 말 늦은 아동의 경우 자음정확도가 높을수록 비단 어 따라말하기 수행이 우수하였다. 말 늦은 아동과 정상아동 모두 자음정확도의 평균은 유사하였지만 말 늦은 아동이 일반아동보다 2 배나 높은 표준편차를 나타내어 비단어 따라말하기와 자음정확 
도가 높은 상관관계를 보였다. 언어장애아동의 비단어 따라말하기 를 살펴본 Yang, Yim, Kim 그리고 Han (2013)은 경기지역 2-6세 어 휘발달지체 및 일반아동, 총 38 명을 대상으로 비단어 따라말하기 와 우연학습 과제를 실시하였다. 우연학습 과제란 새로운 어휘를 삽입하여 만든 이야기를 영상으로 시청함으로 빠른 연결능력을 평 가할 수 있는 과제이다. 그 결과, 일반아동의 수용어휘능력을 예측 하는 가장 큰 요인은 우연학습능력이었지만, 어휘발달지체아동의 수용어휘능력을 가장 잘 예측할 수 있는 변인은 비단어 따라말하 기로 나타났다. 조음음운장애아동의 비단어 따라말하기를 살펴본 Lee와 $\operatorname{Sim}$ (2003)은 서울· 경기지역 4세 단순조음음운장애아동과 일반아동, 총 30명을 대상으로 2-6음절 비단어를 이용한 비단어 따 라말하기 과제를 통해 음운기억 수행력을 살펴보았다. 검사어는 습 득시기가 늦은 말소리(/ㅅ/와/ㅈ/계열, /ㄹ/)를 제외한 자음으로 구 성하였고, 발성유형 및 조음위치를 기준으로 유사한 말소리 음절 문항과 상이한 말소리 음절 문항으로 나누어 수행력을 비교하였다. 그 결과, 정상아동은 음절길이가 증가함에 따라 말소리 유사성 효 과가 뚜렷하였지만 단순언어장애아동에게는 말소리 유사성 효과 가 나타나지 않았다. 이러한 결과는 단순언어장애아동에게 비단어 음절길이가 아동의 음운기억 용량을 초과해 말소리 유사성 여부가 아동에게 비단어를 기억하는 데 유용하지 않았다고 해석할 수 있다. 비단어 따라말하기와 관련해서 국내연구가 활발하게 진행되고 는 있으나, 5 세 이하의 어린 연령을 대상으로 한 대규모 자료의 표준 화된 비단어 따라말하기 과제가 국내에는 아직 발표되지 않았다. 또한 말-언어능력과 관련된 다양한 요인과 비단어 따라말하기 수 행력의 관계를 살펴보는 연구는 아직 부족한 실정이다. 특히 영어 권 국가의 언어치료 임상현장에서는 비교적 적은 수의 비단어 리 스트를 토대로 따라말하기를 실시하여 언어 또는 말소리 장애아동 을 빠르게 선별하고 있다(Gathercole \& Baddeley, 1996; Shriberg \& Lohmeier, 2008). 더 나아가 실제로 비단어 따라말하기 과제를 임 상에서 평가자료로 사용하기 위해서는 비단어 따라말하기 수행과 관련이 있는 변인, 특히 말.언어 영역에서 어떠한 요인과 관련이 있 는지 살펴볼 필요가 있다. 본 연구는 표준화된 비단어 따라말하기 검사도구 개발을 위한 기초 작업으로서 만 3-5세 일반아동을 대상 으로 비단어 따라말하기의 발달 패턴을 살펴보았으며, 연령, 어휘 및 조음능력과 비단어 따라말하기의 관계를 살펴보았다.

\section{연구 방법}

\section{대상자}

서울, 강원도, 경상도, 충청도, 전라도 지역에 거주하는 3 세 37 명,
Table 1. Characteristics of participants

\begin{tabular}{lcccc}
\hline & \multicolumn{3}{c}{ Age group } & Total \\
\cline { 2 - 4 } & 3-yr (N=37) & $4-y r(\mathrm{~N}=52)$ & $5-y r(\mathrm{~N}=52)$ & $(\mathrm{N}=141)$ \\
\hline Gender (boy:girl) & $16: 21$ & $27: 25$ & $27: 25$ & $70: 71$ \\
Province & & & & \\
Seoul & 23 & 26 & 26 & 75 \\
Gangwon-do & 6 & 9 & 17 & 32 \\
Chungcheong-do & 3 & 5 & 3 & 11 \\
Gyeongsang-do & 0 & 7 & 5 & 12 \\
Jeolla-do & 5 & 5 & 1 & 11 \\
\hline
\end{tabular}

4 세 52명, 5세 52명으로 총 141 명(남아 74명, 여아 67명)의 일반아동 을 대상으로 연구를 실시하였다. 본 연구 대상자의 정보는 Table 1 에 제시하였다. 대상자 선정 기준은 유치원 및 어린이집 교사 혹은 양육자 보고에 의해 (1) 발달적으로 이상이나 지체와 관련된 의학 적인 진단이 없는 아동, (2) 이전 또는 현재에 중이염이 없으며 청력 손상이 없는 아동, (3) 구강 구조 및 기능에 문제가 없는 아동, (4) 뚜 렷한 인지나 신경, 혹은 정서장애를 보이지 않는다고 보고된 아동, (5) 아동용 발음평가(Assessment of Phonology and Articulation for Children, APAC; Kim, Pae, \& Park, 2007)에서 16\%ile 이상에 해당하는 아동을 대상으로 하였다.

\section{검사도구}

본 연구에서는 아동의 어휘력 및 조음능력을 확인하기 위하여 다음과 같은 과제들을 실시하였다.

\section{수용·표현어휘력검사}

대상자의 어휘력을 측정하기 위해 수용·표현어휘력검사(Receptive \& Expressive Vocabulary Test, REVT; Kim, Hong, Kim, Jang, \& Lee, 2009)를 실시하였다. 검사는 검사도구의 매뉴얼에 제시된 절 차와 방법을 따라 그대로 진행하였다. 본 연구에서 수용·표현어휘 력검사의 결과는 대상자의 비단어 따라말하기 능력과의 관계를 살 펴보는 하나의 변수로써 사용되었으며, 수용 및 표현어휘 원점수를 통계분석에 사용하였다.

\section{아동용 발음평가}

대상자의 조음능력을 살펴보기 위해 아동용 발음평가(APAC) 를 실시하였으며, 자음정확도를 산출하였다.

\section{비단어검사}

비단어검사는 현재 제작중인 아동 조음음운능력 프로파일(Ha 
$\& \mathrm{Kim}, 2017)$ 의 하위 검사인 비단어검사 항목을 이용하였다. 비단 어검사의 문항은 2-5음절로 구성되었으며 총 25문항이다. 비단어 는 2 음절 10 개, 3 음절 7 개, 4 음절 5 개, 5 음절 3 개로 구성하였다. 1 번 부터 3 번까지는 모음으로만 구성하였고, 4 번부터 25 번까지는 자음 을 포함시켰다. 3-5세 아동의 일반적인 자음 습득 수준을 고려하여 늦게 발달하는 초성 파찰음, 마찰음, 탄설음은 제외하였다. 초성에 서는 일찍 습득하는 파열음과 비음을 포함하였다. 종성은 'ㄷ을 제 외한 모든 종성 자음을 포함하였다. 아동이 반응하지 않거나 검사 어 듣기를 재요청 했다면, 1 회 반응을 허용하였다. 아동이 연속적 으로 무반응을 보일 경우 검사를 일시 중단하고 30 분의 휴식 뒤에 다시 평가하였다. 이후에도 무반응을 보일 시에는 오반응으로 간 주하였다. 아동이 본인의 발화를 자발적으로 수정한 경우에는 수 정한 반응을 최종 반응으로 간주하였다. 본 연구에 사용된 비단어 검사항목은 Appendix 1에 제시하였다.

\section{단어검사}

$\mathrm{APAC}$ 외에도 아동 조음음운능력 프로파일( $\mathrm{Ha} \& \mathrm{Kim}, 2017)$ 의 하위검사 항목인 단어검사를 실시하여 비단어 따라말하기와 조음 능력 간의 관계를 추가로 살펴보았다. 단어 과제는 음절구조와 음 소 난이도를 점진적으로 증가시켜 1음절 5 개, 2 음절 15 개, 3 음절 5 개, 4 음절 3 개, 5 음절 2 개로 총 30 문항으로 구성하여 음절구조와 길이에 따라 아동의 조음능력을 확인할 수 있게 하였다. 음소는 모 든자음과 단모음, 이중모음 중/ㅆ//와/月/가 포함되어 있다. 단어 검 사는 APAC과 동일한 방식으로 그림으로 제시하여 아동이 자발적 으로 단어를 산출하도록 하였다. 본 연구에서 사용한 단어검사는 Appendix 2에 제시하였다

\section{자료수집}

연구자는 조용한 환경에서 대상 아동을 마주보고 앉아 과제를 실시하였다. 자료수집은 비단어 따라말하기와 단어검사를 포함하 고 있는 아동 조음음운능력 프로파일과 APAC, REVT를 이용해 이루어졌다. 순서 효과를 통제하기 위해 자료수집 시 아동들에게 세 가지 검사도구의 실시 순서를 균형을 맞추어 진행하였다, 즉 일 부 아동은 APAC, REVT, 조음음운능력 프로파일의 순서로, 일부 아동은 조음음운능력 프로파일과, APAC, REVT 등의 순서로 검 사를 실시하였다. 각 과제를 완료하면 그 다음 과제까지 5 분의 휴식 시간을 두어 아동의 주의를 환기해주었다. 과제를 시작하기에 앞서 평가자는 아동이 과제 이해에 어려움을 느끼지 않도록 충분히 설 명하였다. 아동이 지루해할 때마다 연구자는 아동이 과제에 집중 할 수 있도록 환기시키고 아동을 격려하였다. 비단어 따라말하기
문항은 각각 한 번씩 청각적으로 제시하였다. 비디오 녹화 및 녹음 으로 모든 아동의 반응을 수집하였다. 아동의 반응은 현장에서 바 로 전사하였고 이후 녹음자료를 토대로 전사 결과를 점검 및 보완 하였다.

\section{비단어 및 단어검사의 자료분석}

아동이 산출한 비단어와 단어의 경우 아동용 조음음운능력 프 로파일검사에서 제안한 방법대로 점수를 산출하였다. 점수체계는 Ingram과 Ingram (2001)이 제안한 평균음운길이(phonological mean length of utterance)의 계산 방법과 비슷하게 기본적으로 음 소의 정확성과 상관없이 자음, 모음을 산출할 경우 1 점씩 부여하고 자음의 정확성 여부에 따라 추가점수를 부여하는 방식으로 이루 어졌다. 비단어 따라말하기 점수는 초성, 모음, 종성 산출 시 1점을 주었고, 초성 정조음 시 1점을 추가하였으며, 총점은 301점이었다. 단어 길이 점수는 초성 자음, 활음, 모음, 종성 자음 산출 시 1 점을 주었다. 단, 겹자음은 초성에만 점수를 주고 종성에는 점수를 주지 않았다. 단어 길이 점수의 총점은 157 점이었다. 단어 길이 점수에 기여한 음소에 대해 정조음 시 1-2점의 음소 점수를 주었다. 모음은 정조음 시 1 점을 주었고, 자음은 조음위치, 조음방법, 발성유형 정 조음 시 1 점 또는 2 점을 주었다. 단어 음소 점수의 총점은 203점이 었다.

\section{신뢰도}

전체 자료의 $20 \%$ 에 해당하는 29 명의 비단어 따라말하기와 단어 검사자료를 무작위로 선정하여 재분석하였다. 평가자 내 신뢰도를 위해서 제 1 저자가 전사한 1 차 자료와 일주일 후에 다시 전사한 2 차 자료를 비교하여 서로 일치한 반응수를 전체 자료 수로 나누고 100 을 곱한 결과 평가자 내 신뢰도는 $94.35 \%$ 이었다. 평가자 간 신뢰도 는 연구자와 언어병리학 석사과정의 학생 1 명이 독립적으로 전사 하여 구한 결과 $90.73 \%$ 로 나타났다.

\section{통계분석}

연령에 따라 비단어 따라말하기 점수가 유의미한 차이를 보이는 지 살펴보기 위해서 일원분산분석(one-way ANOVA)을 실시하였 다. 유의한 차이가 있는 경우에는 Tukey 사후검정을 실시하였다. 비단어 따라말하기와 관련 요인과의 관계를 살펴보기 위해서 예측 변수에 대한 Pearson의 상관관계와 단계적다중회귀분석(stepwise multiple regression)을 실시하였다. 모든 자료는 SPSS 23.0을 사용 하여 분석하였다. 
Table 2. Nonword repetition scores by age group

\begin{tabular}{lcccc}
\hline & \multicolumn{3}{c}{ Age group } & Total \\
\cline { 2 - 4 } & $3-y r$ & $4-y r$ & $5-y r$ & $288.92(10.44)$ \\
Nonword repetition score & $284.75(13.94)$ & $287.73(9.66)$ & $293.09(6.09)$ & 95.98 \\
Correct ratio (\%) & 94.60 & 95.59 & 97.37 & 97 \\
\hline
\end{tabular}

Values are presented as mean (SD).

aPossible highest syllable score is 301.

Table 3. Descriptive statistics of predictive variables of nonword repetition

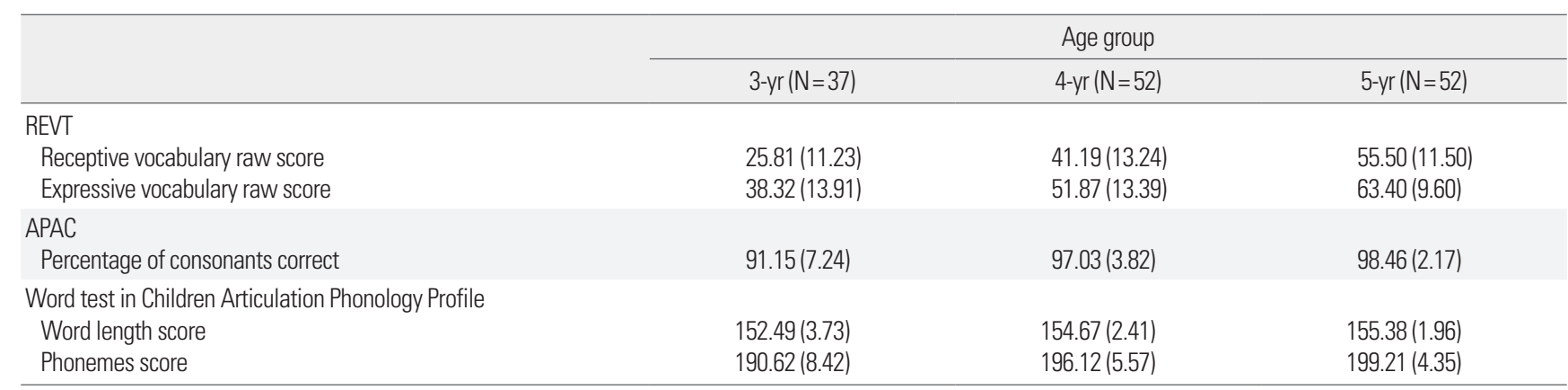

Values are presented as mean (SD).

REVT= Receptive \& Expressive Vocabulary Test (Kim, Hong, Kim, Jang, \& Lee, 2009); APAC=Assessment of Phonology and Articulation for Children (Kim, Pae, \& Park, 2007).

Table 4. Results of stepwise regression analysis

\begin{tabular}{lrrrrr}
\hline & $\mathrm{B}$ & $\beta$ & $t$ & $p$-value & $\mathrm{R}^{2}$ (adj. R) \\
\hline Model 1 & & & & & $.249(.244)$ \\
$\quad$ (constant) & 12.326 & & .302 & .763 & \\
$\quad$ Word length score & 1.792 & .499 & 6.788 & .000 & \\
Model 2 & & & & & $.325(.316)$ \\
$\quad$ (constant) & 74.533 & & 1.781 & .077 & \\
$\quad$ Word length score & 1.337 & .372 & 4.840 & .000 & \\
Receptive vocabulary & .189 & .304 & 3.952 & .000 & \\
\hline
\end{tabular}

Dependent variable is nonword repetition score.

\section{연구 결과}

\section{연령에 따른 비단어 따라말하기 점수}

일반아동의 연령에 따른 비단어 따라말하기 수행력의 기술통계 결과는 Table 2와같다.

3 세 아동의 비단어 따라말하기 점수는 평균 284.75 점( $\mathrm{SD}=13.94)$ 으로 정반응률은 $94.60 \%, 4$ 세는 평균 287.73 점 $(\mathrm{SD}=9.66)$, 정반응 률 95.59\%로, 5 세는 평균 293.09점(SD=6.09), 정반응률은 $97.37 \%$ 로 나타났다.

연령에 따라 비단어 따라말하기 수행력에 유의미한 차이가 있는 지 알아보기 위해 일변량분산분석(one-way ANOVA)을 실시한 결 과, 연령에 따라 비단어 따라말하기 점수는 유의미한 차이를 보였
다 $\left(F_{(2,138)}=8.194, p<.01\right)$. Tukey HSD 사후분석을 실시한 결과, 비 단어 따라말하기는 3세 아동과 5세 아동 간에 유의한 차이가 나타 났고, 4 세 아동과 5 세 아동 간에도 유의한 차이가 나타났다. 3 세 아 동과 4 세 아동은 유의한차이를 보이지 않았다.

\section{비단어 따라말하기와 관련 요인간의 관계}

본 연구에서는 비단어 따라말하기 수행력과 관련이 있다고 보고 된 요인들 중 연령, 수용어휘력, 표현어휘력, 조음능력과 비단어 따 라말하기 점수와의 관계를 살펴보았다. 어휘력은 REVT 수용·표현 어휘 원점수, 조음능력은 아동용 조음음운능력 프로파일검사 중 단어 길이 점수와 단어 음소 점수, $\mathrm{APAC}$ 자음정확도를 통해 살펴 보았다. 비단어 따라말하기 점수와 관련된 요인의 각 연령집단별 기술통계는 Table 3과 같다.

\section{상관분석}

비단어 따라말하기와 연령, 수용어휘 원점수, 표현어휘 원점수, $\mathrm{APAC}$ 자음정확도, 단어 길이 점수, 단어 음소 점수의 상관관계를 살펴보았다. 비단어 따라말하기 점수는 수용어휘 원점수 $(r=.459$, $p<.01)$, 표현어휘 원점수 $(r=.454, p<.01)$, 단어 길이 점수 $(r=.499$, $p<.01)$, 단어 음소 점수 $(r=.459, p<.01)$ 와 유의미한 양의 상관관계 를 보였다. 비단어 따라말하기 점수는 연령 $(r=.321, p<.01)$, 자음정 확도 $(r=.269, p<.01)$ 와 양의 상관관계를 보였다. 


\section{다중회귀분석}

비단어 따라말하기 점수를 예측하는 독립변수의 다중회귀분석 결과는 Table 4 와 같다.

회귀분석이 적절한지 다중공선성 여부를 검증하기 위하여 분산 팽창인수(Variation Index Factor, VIF) 값을 살펴본 결과, 모든 독 립변인의 VIF 값이 10 미만으로 나타났고, 공차한계가 모두 1 보다 작은 것으로 나타나, 본 연구에서 사용된 독립변수들 간의 다중공 선성의 문제는 없는 것으로 나타났다.

연령, 수용어휘 원점수, 표현어휘 원점수, $\mathrm{APAC}$ 자음정확도, 단어 길이 점수, 단어 음소 점수를 독립변수로 하여 회귀분석을 한 결과, 단어 길이 점수와수용어휘 원점수가 유의미하게 비단어 따라말하 기 점수를 예측하는 것으로 나타났다. 단어 길이 점수가 $\mathrm{R}=.249$ 로 나왔으며, 단어 길이 점수에 추가적으로 수용어휘 원점수가 포함 될 경우 $\mathrm{R}=.325$ 로 나타났다. 따라서 단어 길이 점수가 비단어 따라 말하기 점수를 $24.9 \%$ 를 설명하였으며, 단어 길이 점수와 수용어휘 원점수 두 변인은 비단어 따라말하기 점수를 $32.5 \%$ 를 설명하였다.

\section{논의 및 결론}

본 연구는 만 3-5세 일반아동 141명을 대상으로 연령에 따른 비 단어 따라말하기 수행력의 변화를 살펴보았으며, 비단어 따라말하 기 수행력과 연령, 어휘, 조음능력 간의 관계를 살펴보고자 하였다. 일반아동을 대상으로 연령에 따른 비단어 따라말하기 점수를 살 펴본 결과, 5 세 아동은 3 세, 4 세 아동보다 유의미하게 높은 것으로 나타났고 3세와 4세 아동은 수행 간 유의미한 차이를 보이지 않았 다. 본 연구결과는 본 연구와 동일하게 2-5세 일반아동을 대상으로 비단어 따라말하기 수행을 살펴본 Hwang과 $\mathrm{Ha}$ (2010)의 연구와 비교해 비단어 따라말하기 상의 수행력의 큰 변화를 보이는 연령집 단에 차이가 있다. 본 연구에서는 4-5세에 비단어 따라말하기 수행 력이 가장 크게 발달하였지만, Hwang과 $\mathrm{Ha}$ (2010)의 연구에서는 2-3세에 비약적으로 발달하였다. 비단어 따라말하기 수행력의 큰 발달을 보이는 시기가 두 연구 간에 다르게 나타난 이유는 각 연구 에서 사용한 비단어 검사어의 조음 난이도, 음절길이와 음절구조 상의 차이와 관련이 있다. 각 연구의 검사어를 살펴보면 본 연구에 서는 비음, 파열음, 설측음, 이중모음으로 구성된 2-5음절의 비단어 를 사용하였다. Hwang과 $\mathrm{Ha}$ (2010)의 연구에서는 비음, 파열음으 로 구성된 1-4음절 비단어를 사용하였다. 1,2 음절에는 한국어에서 가능한 모든 음절구조를 포함하였고 3, 4 음절에는 MacArthurBates Communicative Development Inventory-Korean (M-B CDI$\mathrm{K} ; \mathrm{Pae} \& \mathrm{Kwak}$, 2007)에서 제시된 어휘 중 상대적으로 어휘목록수
가 높은 음절구조를 선정하였다. 본 연구에서는 치경파열음을 제외 한 6개의 자음이 종성자음으로 포함되었지만 Hwang과 $\mathrm{Ha}$ (2010) 의 연구에서는 비음과 유음만이 종성자음으로 포함되었다. 또한 채점방식을 살펴보면 본 연구에서는 길이, 초성, 모음, 종성으로 점 수를 구성하였다. 이때 음소의 정확성과 상관없이 자음, 모음을 산 출할 경우 1 점씩 부여하고 음소의 정확성 여부에 따라 1 점을 추가 하는 방식으로 분석하였다. 반면에 Hwang과 $\mathrm{Ha}$ (2010)의 연구에 서는 자음의 정확도에 따라 문항, 음절, 음소별로 정반응률을 분석 하였다.

연령에 따라 비단어 따라말하기 수행력이 향상되는 이유는 아 동의 연령이 증가하면서 비단어 따라말하기 수행을 위하여 필요한 청각변별, 청각정보처리, 말지각 등의 능력들이 함께 발달하기 때 문이다. 작업기억과 음운기억의 측면에서도 연령이 증가하면서 아 동의 전반적인 기억용량이 늘어나고, 제한된 기억용량을 사용하는 처리의 효율성도 증가했다고 볼 수 있다. 비단어 따라말하기 능력 에 영향을 주는 영역들의 발달 및 변화가 연령에 따라 일어나면서 비단어 따라말하기의 수행력 역시 증가했다고 해석해 볼 수 있다 (Hwang, 2015; Hwang \& Ha, 2010; Archibald \& Joanisse, 2009; Chiat \& Roy, 2007; Gathercole \& Baddeley, 1989; Roy \& Chiat, 2004). 또한, 비단어 따라말하기 수행력은 음운기억 및 작업기억 측면의 발달뿐만 아니라 말 산출의 발달과도 관련이 있다. 3 세에 접어들면 서 아동의 조음능력도 향상되고 생략과 첨가와 같은 음운변동이 점차적으로 사라지게 된다(Kim, 1992). 구강 구조와 기능 측면에 서도 크게 발달하고 혀의 움직임도 점차 정교화 된다. 4 세에서는 약 $90 \%$ 의 조음정확도로, 음소 산출이 안정화 된다(Kim \& Pae, 2005). 3세 집단에서는 수행능력의 표준편차가 크게 나타났으며, 이런 결과는 Roy와 Chait (2004)의 연구 결과와 일치하였다. 이러 한 점은 아동의 비단어 따라말하기 수행능력은 연령이 낮을수록 개인차가 컸지만 연령이 증가함에 따라 수행능력이 안정되면서 개 인차가 줄어들었음을 알 수 있다.

비단어 따라말하기 점수는 모든 변인과 유의한 것으로 나타났 다. 통계적으로 유의하였지만 자음정확도와 연령은 각각 .20대, .30 대로 낮은 상관계수를 나타냈고, 수용어휘 원점수, 표현어휘 원점 수, 단어 길이 점수, 단어 음소 점수는 모두 . 40 대의 상관계수를 나 타냈다(Gathercole \& Baddeley, 1989; Roy \& Chiat, 2004). 특히 회 귀분석 결과, 상대적으로 높은 상관계수를 보였던 수용어휘 원점 수, 표현어휘 원점수, 단어 길이 점수, 단어 음소 점수 중에 단어 길 이 점수와 수용어휘력이 비단어 따라말하기의 유의미한 예측변인 으로 나타났다.

아동의 조음음운능력을 반영하는 측정치로서 분석한 자음정확 
도, 단어 길이 점수와 단어 음소 점수 중에서 단어 길이 점수만이 비단어 따라말하기 수행력의 유의미한 예측변인으로 나타났다. 단 어 길이 점수는 음소배열 규칙을 지켜 음소를 산출한 것으로 목표 음소와 정확하게 일치하지 않아도 자음 또는 모음을 산출할 경우 1 점을 부여하였다. 음소 점수보다 길이 점수가 비단어 따라말하기 를 유의하게 예측한다는 것은 비단어 따라말하기 과제가 말 처리 모델에서 음운표상, 음운기억, 음운배열규칙과 좀 더 밀접한 관계 가 있다고 해석해 볼 수 있다. 단어 길이 점수 다음으로 비단어 따라 말하기 수행력의 유의미한 예측변인으로 나타난 수용어휘력과 함 께 결과를 해석해보면 본 연구에서 사용한 비단어 따라말하기 과 제는 말 운동 산출 측면보다는 음운기억, 음운표상, 음운배열규칙, 의미 및 어휘표상 등의 말 처리 과정에서 좀 더 추상적인 단계와 밀 접한 관련이 있음을 보여준다(Gathercole, Willis, Baddeley, \& Emslie, 1994; Shriberg et al., 2009).

음운표상은 장기기억 속에 저장된 단어의 음운정보로써 음운표 상에 문제가 있을 경우 조음 능력에도 어려움이 있다(Stackhouse \& Wells, 1997; Sutherland \& Gillon, 2005). 음운인식과 음운기억 혹 은 작업기억 등의 음운처리 과정은 음운표상을 기반으로 한다. 따 라서 음운표상에 어려움을 보이는 아동은 적절한 음운처리능력을 발휘할 수 없고 이후 말.언어발달에도 부정적인 영향을 줄 수 있다. 단순언어장애아동은 음운기억 혹은 작업기억의 결함으로 인해 음 운적 정보를 저장하는 능력에 어려움이 있다고 설명하였다(Baddeley, 2003; Gathercole, Hitch, \& Martin, 1997). 비단어 따라말하 기 과제가 음운기억을 측정하는 과제로 가장 유용하며 아동들의 음운기억을 가장 민감하게 평가할 수 있다고 하였다(Baddeley et al., 1998). 또한, 비단어를 따라말하기 위해서는 조음 프로그래밍 및 운동 협응과 산출이 원활하게 이루어져야 한다(Sasisekaran et al., 2010; Walsh et al., 2006). 따라서 비단어 따라말하기 수행력으 로 아동의 음운기억, 음운표상, 조음 프로그램 및 산출 능력을 포함 하는 말 처리 능력을 종합적으로 살펴볼 수 있다(Sutherland \& Gillon, 2005).

본 연구에서는 비단어 따라말하기 수행력은 어휘능력 중에서 표 현보다 수용어휘력이 더 관련이 있고 유의미한 예측변인으로 나타 났다. 어휘영역 중 수용어휘력만 유의미한 예측변인으로 나온 이유 는 비단어 따라말하기 과제에서 요구되는 음운기억의 용량, 언어적 인 단기기억, 어휘의 이해 및 조작, 탐색 속도에서의 기능적인 결함 때문이라고 추론해 볼 수 있다. 단순언어장애아동은 음운기억의 결함 때문에 말-언어가 이루어지는 과정에서 정보를 적절하게 저장 하지 못하여 이해에 어려움을 나타낸다(Leonard, 1998; Montgomery, 1995). 비단어 따라말하기 수행의 기저에 깔린 음운기억 및 작
업기억 능력이 단순언어장애아동이 보이는 적은 어휘 및 어휘다양 도, 낱말 재인 및 인출에서의 어려움에 영향을 주었다고 볼 수 있다.

선행연구에서 일반아동과 언어장애아동의 수행력을 비교한 결 과, 언어장애아동이 비단어 따라말하기 수행에서 눈에 띄는 결함 을 나타낸다고 보고하고 있다(Dollaghan \& Campbell, 1998; Weismer et al., 2000). 음운기억 능력이 아동의 초기 어휘발달을 지원하 기 때문에 긴밀한 관련이 있다고 볼 수 있다. 아동들은 약 5 세 이후 점점 더 축적된 어휘지식을 새로운 단어를 습득하는 데 적용할 수 있게 된다. 이러한 어휘지식이 비단어 따라말하기 수행을 지원한다 고 볼 수 있다(Gathercole \& Baddeley, 1989). 비단어 따라말하기 수 행력은 음운처리와 언어학습능력과 같은 언어와 어휘영역과 관련 이 있으며 서로 영향을 주고받는다고 할 수 있다(Gathercole \& Baddeley, 1989; Gathercole, Willis, Emslie, \& Baddeley, 1992). 비단어 따라말하기 과제가 언어 처리와 밀접한 관련이 있으며 아동의 어휘 발달을 살펴보는 중요한 역할을 함에 따라 임상적으로 비단어 따 라말하기 과제가 언어 처리에 어려움을 보이는 아동을 선별하는 유용하게 사용 될 수 있음을 제안한다(Chiat \& Roy, 2007; Roy \& Chiat, 2004; Stokes \& Klee, 2009; Weismer et al., 2000).

본 연구는 5 세 이하의 어린 연령대의 일반아동 141 명을 대상으 로 검사를 실시하였고, 비단어 따라말하기 수행력과 어휘, 조음 영 역 간의 관계를 살펴봄으로써 비단어 따라말하기 과제의 임상적 유용성을 점검하였다. 본 연구에서 사용된 과제가 표준화되고 임 상에서 타당하고 신뢰도 높은 검사도구로써 사용되기 위해서는 추 후 지속적인 연구가 필요하다. 본 연구결과에서 연령에 따라 비단 어 따라말하기 점수는 유의미하게 나타났지만, 3 세 아동의 비단어 따라말하기 점수 정반응률은 $94.60 \%, 4$ 세는 $95.59 \%, 5$ 세는 $97.37 \%$ 로 수행력 증가의 폭이 낮게 나타났다. 특히, 5 세의 비단어 따라말 하기 정반응률이 $97.37 \%$ 로 나타나 6-7세 아동에게 확대하여 비단 어 따라말하기 수행력을 살펴볼 필요가 있다. 그리고 3세에 이미 $94.60 \%$ 의 높은 정반응률을 보였으므로 2 세 아동을 대상으로 수 행력을 살펴볼 필요가 있겠다. 2 세 아동은 짧은 주의집중과 과제 이해의 어려움 등으로 인해 과제 수행에 있어서 제한은 있겠으나, 과제 수행 여부와 정확도를 중심으로 2세 아동의 비단어 따라말하 기 능력도 살펴보면 말.언어발달에 대한 보다 포괄적인 정보를 얻 을 수 있을 것이다. 또한, 자료수집 과정에서 서울지역 아동에 비해 강원도, 충청도, 경상도, 전라도지역 아동의 수행력이 비교적 낮은 것이 관찰되었다. 실제로 $t$ 통계 분석을 실시한 결과, 5 세에서 지역 간 유의한 차이가 나타났다 $(t=4.300, p=.001)$. 서울지역 5 세 아동 의 비단어 따라말하기 평균 점수는 296.23점 $(\mathrm{SD}=5.10)$ 으로, 타지 역(강원도, 충청도, 경상도, 전라도)의 비단어 따라말하기 점수의 
평균은 289.96점 $(\mathrm{SD}=5.41)$ 으로 나타났다. 추후연구에서는 보다 많은 수의 대상자를 대상으로 지역 또는 사회경제적 수준에 따른 비단어 따라말하기 능력에 차이가 있는지 자세히 살펴볼 필요가 있겠다.

\section{REFERENCES}

Archibald, L. M., \& Joanisse, M. F. (2009). On the sensitivity and specificity of nonword repetition and sentence recall to language and memory impairments in children. Journal of Speech, Language, and Hearing Research, $52,899-914$.

Baddeley, A. (1986). Working memory. New York, NY: Oxford University Press. Baddeley, A. (2003). Working memory and language: an overview. Journal of Communication Disorders, 36, 189-208.

Baddeley, A., Gathercole, S., \& Papagno, C. (1998). The phonological loop as a language learning device. Psychological Review, 105, 158-173.

Bortolini, U., Arfé, B., Caselli, C. M., Degasperi, L., Deevy, P., \& Leonard, L. B. (2006). Clinical markers for specific language impairment in Italian: the contribution of clitics and non-word repetition. International Journal of Language \& Communication Disorders, 41, 695-712.

Chiat, S., \& Roy, P. (2007). The Preschool Repetition Test: an evaluation of performance in typically developing and clinically referred children. Journal of Speech, Language, and Hearing Research, 50, 429-443.

Dispaldro, M., Leonard, L. B., \& Deevy, P. (2013). Real-word and nonword repetition in Italian-speaking children with specific language impairment: a study of diagnostic accuracy. Journal of Speech, Language, and Hearing Research, 56, 323-336.

Dollaghan, C., \& Campbell, T. F. (1998). Nonword repetition and child language impairment. Journal of Speech, Language, and Hearing Research, 41, 1136-1146.

Gathercole, S. E. (2006). Nonword repetition and word learning: the nature of the relationship. Applied Psycholinguistics, 27, 513-543.

Gathercole, S. E., \& Baddeley, A. D. (1989). Evaluation of the role of phonological STM in the development of vocabulary in children: a longitudinal study. Journal of Memory and Language, 28, 200-213.

Gathercole, S. E., \& Baddeley, A. D. (1996). The children's test of nonword repetition. London: Psychological Corporation.

Gathercole, S. E., Hitch, G. J., \& Martin, A. J. (1997). Phonological short-term memory and new word learning in children. Developmental Psychology, 33, 966-979.
Gathercole, S. E., Willis, C. S., Baddeley, A. D., \& Emslie, H. (1994). The children's test of nonword repetition: a test of phonological working memory. Memory, 2, 103-127.

Gathercole, S. E., Willis, C. S., Emslie, H., \& Baddeley, A. D. (1992). Phonological memory and vocabulary development during the early school years: a longitudinal study. Developmental Psychology, 28, 887-898.

Ha, S., \& Kim, M. (2017). Children Articulation and Phonology Profile. Manuscript in preparation.

Hwang, J., \& Ha, S. (2010). Nonword repetitions of 2- to 5-year-old typically developing children. Korean Journal of Communication Disorders, 15, 561571.

Hwang, M. (2015). Nonword repetition of typically developing children. Communication Sciences \& Disorders, 20, 374-385.

Ingram, D., \& Ingram, K. D. (2001). A whole-word approach to phonological analysis and intervention. Language, Speech, and Hearing Services in Schools, $32,271-283$.

Kim, M. J., \& Pae, S. (2005). The percentage of consonants correct and the ages of consonantal acquisition for 'Korean-Test of Articulation for Children (K-TAC)'. Korean Journal of Speech Sciences, 12, 139-149.

Kim, M. J., Pae, S., \& Park, C. I. (2007). Assessment of phonology for children (APAC). Incheon: Human Brain

Kim, Y. T. (1992). A study of phonological regression in 2-6 years of age: omission and addition patterns. Journal of Rehabilitation Science, 10, 49-54.

Kim, Y. T., Hong, G. H., Kim, K. H., Jang, H. S., \& Lee, J. Y. (2009). Receptive \& expressive vocabulary test (REVT). Seoul: Seoul Community Rehabilitation Center.

Lee, E. J., \& Sim, H. S. (2003). Phonological memory in the nonword repetition of children: a comparison of functional phonologically disordered and normal children. Korean Journal of Communication Disorders, 8, 127-145.

Lee, H. J. (2010). The influences of number of syllables and wordlikeness on 3-to 5-year-old Korean-English bilingual children's nonword repetition (Master's thesis). Ewha Womans University, Seoul, Korea.

Leonard, L. B. (1998). Children with specific language impairment. Cambridge, MA: MIT Press.

Montgomery, J. W. (1995). Sentence comprehension in children with specific language impairment: the role of phonological working memory. Journal of Speech, Language, and Hearing Research, 38, 187-199.

Oh, D. Y., \& Yim, D. (2013). Non-word repetition and sentence repetition performance in 2-3 years old late talkers and normal children. Communication Sciences \& Disorders, 18, 277-287. 
Pae, S., \& Kwak, K. C. (2007). Korean MacArthur-Bates Communicative Development Inventories (K M-B CDI). Seoul: Mindpress.

Roy, P., \& Chiat, S. (2004). A prosodically controlled word and nonword repetition task for 2- to 4-year-olds: evidence from typically developing children. Journal of Speech, Language, and Hearing Research, 47, 223-234.

Sahlen, B., Reuterskiold-Wagner, C., Nettelbladt, U., \& Radeborg, K. (1999). Non-word repetition in children with language impairment-pitfalls and possibilities. International Journal of Language \& Communication Disorders, 34, 337-352.

Sasisekaran, J., Smith, A., Sadagopan, N., \& Weber-Fox, C. (2010). Nonword repetition in children and adults: effects on movement coordination. Developmental Science, 13, 521-532.

Shriberg, L. D., \& Lohmeier, H. L. (2008). The Syllable Repetition Task (SRT). Madison, WI: University of Wisconsin-Madison, Waisman Center.

Shriberg, L. D., Lohmeier, H. L., Campbell, T. F., Dollaghan, C. A., Green, J. R., \& Moore, C. A. (2009). A nonword repetition task for speakers with misarticulations: the Syllable Repetition Task (SRT). Journal of Speech, Language, and Hearing Research, 52, 1189-1212.

Stackhouse, J., \& Wells, B. (1997). Children's speech and literacy difficulties. I: A psycholinguistic framework. London: Whurr Publishers.

Stark, R. E., \& Blackwell, P. B. (1997). Oral volitional movements in children with language impairments. Child Neuropsychology, 3, 81-97.

Stokes, S. F., \& Klee, T. (2009). The diagnostic accuracy of a new test of early nonword repetition for differentiating late talking and typically developing children. Journal of Speech, Language, and Hearing Research, 52, 872-882.

Stokes, S. F., Wong, A. M., Fletcher, P., \& Leonard, L. B. (2006). Nonword repetition and sentence repetition as clinical markers of specific language impairment: the case of Cantonese. Journal of Speech, Language, and Hearing Research, 49, 219-236.

Sutherland, D., \& Gillon, G. T. (2005). Assessment of phonological representations in children with speech impairment. Language, Speech, and Hearing Services in Schools, 36, 294-307.

Walsh, B., Smith, A., \& Weber-Fox, C. (2006). Short-term plasticity in children's speech motor systems. Developmental Psychobiology, 48, 660-674.

Weismer, S. E., Tomblin, J. B., Zhang, X., Buckwalter, P., Chynoweth, J. G., \& Jones, M. (2000). Nonword repetition performance in school-age children with and without language impairment. Journal of Speech, Language, and Hearing Research, 43, 865-878.

Yang, Y., Yim, D., Kim, S., \& Han, J. (2013). The relationship among receptive vocabulary, non-word repetition, and quick incidental learning in preschoolers with and without delay in vocabulary development. Communication Sciences \& Disorders, 18, 379-391. 
Appendix 1. 비단어 따라말하기 검사어

\begin{tabular}{|c|c|}
\hline 번호 & 검사어 \\
\hline 1 & 에오 \\
\hline 2 & 어으아 \\
\hline 3 & 우이위 \\
\hline 4 & 어뻐 \\
\hline 5 & 뿌뿌 \\
\hline 6 & 띠뚜 \\
\hline 7 & 마누 \\
\hline 8 & 꼬니 \\
\hline 9 & 까밤 \\
\hline 10 & 감타 \\
\hline 11 & 웁띨 \\
\hline 12 & 댕급 \\
\hline 13 & 다마마 \\
\hline 14 & 양끼누 \\
\hline 15 & 덕뿌기 \\
\hline 16 & 무각땅 \\
\hline 17 & 당딤맨 \\
\hline 18 & 이푸띠아 \\
\hline 19 & 가나버디 \\
\hline 20 & 빠우매뿔 \\
\hline 21 & 발디보누 \\
\hline 22 & 부나봉일 \\
\hline 23 & 올리두이까 \\
\hline 24 & 이오드기남 \\
\hline 25 & 간기네온디 \\
\hline
\end{tabular}

Appendix 2. 단어 검사어

\begin{tabular}{|c|c|}
\hline 번호 & 검사어 \\
\hline 1 & 입 \\
\hline 2 & 코 \\
\hline 3 & 눈 \\
\hline 4 & 책 \\
\hline 5 & 별 \\
\hline 6 & 오이 \\
\hline 7 & 엄마 \\
\hline 8 & 악어 [아거] \\
\hline 9 & 새우 \\
\hline 10 & 뽀뽀 \\
\hline 11 & 치즈 \\
\hline 12 & 매미 \\
\hline 13 & 그네 \\
\hline 14 & 두개 \\
\hline 15 & 가방 \\
\hline 16 & 도둑 \\
\hline 17 & 라면 \\
\hline 18 & 단추 \\
\hline 19 & 밥통 \\
\hline 20 & 풍선 \\
\hline 21 & 바나나 \\
\hline 22 & 피아노 \\
\hline 23 & 떡볶이 [떡뽀끼] \\
\hline 24 & 목욕탕 [모곡탕] \\
\hline 25 & 선생님 \\
\hline 26 & 할아버지 [하라버지] \\
\hline 27 & 파인애플 [파이내플] \\
\hline 28 & 미끄럼틀 \\
\hline 29 & 엘리베이터 \\
\hline 30 & 아이스크림 \\
\hline
\end{tabular}




\section{국문초록}

\section{비단어 따라말하기와 연령, 어휘 및 조음능력과의 관계}

정소미 ${ }^{1}$ 하승희 ${ }^{2}$

'한림대학교 보건과학대학원 언어병리학과, 2 한림대학교 언어청각학부·한림청각언어연구소

배경 및 목적: 3-5세 일반아동들을 대상으로 연령에 따른 비단어 따라말하기 수행력을 살펴보고, 비단어 따라말하기와 연령, 어휘 및 조음능력과의 관계를 살펴보았다. 방법: 3 세 37 명, 4 세 52명, 5 세 52명으로 총 141 명으로부터 비단어 따라말하기 검사와 단어 검사, 아 동용 발음평가(APAC), 수용·표현어휘력 검사(REVT)를 실시하였다. 비단어 따라말하기 점수, 단어 길이점수, 단어 음소점수, APAC 자음정확도, REVT의 수용 및 표현어휘 원점수를 구하였다. 결과: 비단어 따라말하기 점수는 5 세 아동이 3 세와 4 세 아동 보다 유의미 하게 높았으며, 3 세 아동과 4 세 아동은 유의미한 차이를 보이지 않았다. 비단어 따라말하기 점수와 연령, 단어 길이점수, 단어 음소점수, REVT 수용 원점수, REVT 표현 원점수, 자음정확도는 양의 상관관계를 나타냈다. 회귀분석 결과, 단어 길이점수와 REVT 수용어휘 원 점수가 비단어 따라말하기 점수를 유의미하게 예측하였다. 논의 및 결론: 본 연구결과는 비단어 따라말하기를 통해 일반아동의 조음 능력과 수용어휘능력을 간접적으로 파악할 수 있으며, 말.언어발달상의 문제를 보이거나 보일 확률이 높은 아동을 선별할 수 있음을 지지한다.

핵심어: 비단어 따라말하기, 연령, 어휘, 조음능력

본 논문에서 사용한 단어 및 비단어 검사의 채점방식을 제안해 주시고, 원고 작성에 도움 주신 김민정 선생님께 감사를 드립니다.

\section{참고문헌}

김민정, 배소영(2005). 아동용 조음검사를 이용한 연령별 자음정확도와 우리말 자음의 습득연령. 음성과학, 12, 139-149.

김민정, 배소영, 박창일(2007). 아동용 발음평가(APAC). 서울: 휴브알앤씨.

김영태(1992). 2-6세아동의 음운변동에 관한 연구(I): 생략 및 첨가 변동을 중심으로. 재활과학연구, 10, 49-54.

김영태, 홍경훈, 김경희, 장혜성, 이주연(2009). 수용·표현어휘력검사(REVT). 서울: 서울장애인종합복지관.

배소영, 곽금주(2007). 한국판 맥아더-베이츠 의사소통발달평가 (K M-B CDI). 서울: 마인드프레스.

양윤희, 임동선, 김신영, 한지윤(2013). 학령 전 어휘발달지체 및 일반아동의 비단어 따라 말하기, 빠른 우연학습과 수용어휘와의 관계. 언어청각장애

연구, 18, 379-391.

오다연, 임동선(2013). 2-3세 말 늦은 아동과 정상아동의 비단어따라말하기와 문장 따라말하기 수행 능력. 언어청각장애연구, 18, 277-287.

이은주, 심현섭(2003). 무의미 음절 따라말하기를 통한 단순조음음운장애아동과 정상아동의 음운기억 수행능력 비교연구. 언어청각장애연구, 8,

127-145.

이현정(2010). 음절길이와 단어유사성이 3-5세 한국어-영어 이중언어아동의 비단어 따라말하기 수행에 미치는 영향. 이화여자대학교 석사학위논문. 하승희, 김민정(2017). 아동 조음음운능력 프로파일. 출판예정.

황민아(2015). 일반아동의 비단어 따라말하기. 언어청각장애연구, 20,374-385.

황진경, 하승희(2010). 2-5세 일반아동의 무의미단어 따라말하기. 언어청각장애연구, 15, 561-571. 